\title{
Theology in the flesh - embodied sensing, consciousness and the mapping of the body
}

\begin{tabular}{|c|c|}
\hline $\begin{array}{l}\text { Author: } \\
\text { Jacob Meiring }\end{array}$ & \\
\hline $\begin{array}{l}\text { Affiliation: } \\
{ }^{1} \text { Department } \\
\text { and Christian } \\
\text { of Theology, } \\
\text { Pretoria, Sout }\end{array}$ & $\begin{array}{l}\text { ff Dogmatics } \\
\text { Ethics, Faculty } \\
\text { Iniversity of } \\
\text { h Africa }\end{array}$ \\
\hline $\begin{array}{l}\text { Project leade } \\
\text { Project numb }\end{array}$ & $\begin{array}{l}\text { : J. Buitendag } \\
\text { er: } 02402343\end{array}$ \\
\hline $\begin{array}{l}\text { Description: } \\
\text { Dr Jacob Meir } \\
\text { the research } \\
\text { 'Theology of I } \\
\text { by Prof. Dr Jol } \\
\text { (Dean, Facult' } \\
\text { Department L } \\
\text { Christian Ethi } \\
\text { Theology, Uni } \\
\text { Pretoria.) }\end{array}$ & $\begin{array}{l}\text { ing is part of } \\
\text { roject, } \\
\text { Jature', directed } \\
\text { lan Buitendag } \\
\text { of Theology, } \\
\text { ogmatics and } \\
\text { s, Faculty of } \\
\text { versity of }\end{array}$ \\
\hline $\begin{array}{l}\text { Correspondin } \\
\text { Jacob Meiring } \\
\text { jacob@bodyt }\end{array}$ & $\begin{array}{l}\text { g author: } \\
\text { ',eology.co.za }\end{array}$ \\
\hline $\begin{array}{l}\text { Dates: } \\
\text { Received: } 11 \\
\text { Accepted: } 11 \\
\text { Published: } 30\end{array}$ & $\begin{array}{l}\text { Apr. } 2016 \\
\text { Aug. } 2016 \\
\text { Sept. } 2016\end{array}$ \\
\hline $\begin{array}{l}\text { How to cite th } \\
\text { Meiring, J., } 20 \\
\text { in the flesh - } \\
\text { sensing, conss } \\
\text { the mapping } \\
\text { HTS Teologies } \\
\text { Theological St } \\
\text { a3429. http:// } \\
\text { org/10.4102/l }\end{array}$ & $\begin{array}{l}\text { is article: } \\
\text { 16, 'Theology } \\
\text { embodied } \\
\text { iousness and } \\
\text { f the body', } \\
\text { e Studies/ } \\
\text { udies 72(4), } \\
\text { dx.doi. } \\
\text { t.s.v72i4.3429 }\end{array}$ \\
\hline $\begin{array}{l}\text { Copyright: } \\
\text { (c) 2016. The } \\
\text { Licensee: AOS } \\
\text { is licensed un } \\
\text { Creative Comr } \\
\text { Attribution Lic }\end{array}$ & $\begin{array}{l}\text { ISthors. } \\
\text { IS. This work } \\
\text { der the } \\
\text { nons } \\
\text { ense. }\end{array}$ \\
\hline Read online: & \\
\hline 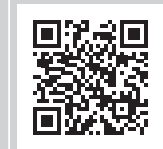 & $\begin{array}{l}\text { Scan this QR } \\
\text { code with your } \\
\text { smart phone or } \\
\text { mobile device } \\
\text { to read online. }\end{array}$ \\
\hline
\end{tabular}

\section{Author:}

Affiliation

${ }^{1}$ Department of Dogmatics of Theology,

Pretoria, South Africa

Project leader: J. Buitendag

Description:

Dr Jacob Meiring is part of

'Theology of Nature', directed Department Dogmatics and Christian Ethics, Faculty of

Theology, University of

Jacob Meiring

Dates:

Received: 11 Apr. 2016

Accepted: 11 Aug. 2016

in the flesh-embodied

sensing, consciousness and

3429. http://dx doi.

Copyright:

(C) 2016. The Authors. Licensee: AOSIS. This work

is licensed under the

Creative Commons
Flowing from his model for a contemporary theological anthropology as embodied sensing, the author focuses on the corporeal-linguistic turn in the 21st century and explores how his use of bodymapping, as an applied aspect of theological anthropology within the context of narrative therapy, intersects with the work of the neuro-scientist, Antonio Damasio on consciousness, and specifically his research on how the brain constantly maps the body in the brain. The author also explores the notion of sensing in the latest book of the Irish philosopher Richard Kearney and based on this, expands his model for theological anthropology to the embodied sensing of meaning.

\section{Introduction}

The Italian philosopher, historian and jurist Giambattista Vico wrote the following:

It is ... beyond our power to enter into the vast imagination of those first men, whose minds were not in the least abstract, refined, or spiritualized, because they were entirely immersed in the senses, buffeted by their passions, buried in the body. (Vico 1968:118)

This he wrote in his book, The New Science of Giambattista, published in 1725. In the centuries since this publication scientists, philosophers and theologians have endeavoured to pierce the imagination and senses of the first men, and in a discipline like theological anthropology with its questions around human uniqueness and what it means to be human in relation to God, these questions have shifted to include inquiries regarding personhood, the notion of self, the 'soul', the evolution of religious awareness and consciousness.

In my own research I have traced the turn back to the body in the 20th and 21st centuries in a variety of disciplines as well as in theology and theological anthropology, and have argued that it is more correct to speak of a third generation corporeal turn that encompasses a striking convergence of the corporeal and linguistic turn (Meiring 2015:5 of 8). This corporeallinguistic turn was bolstered by research in cognitive science and cognitive linguistics with its focus on how language is expressed from the body as well as the influence of metaphorical thinking.

Vico continues that when humans 'wish to give utterance to our understanding of spiritual things, we must seek aid from our imagination to explain them'. In contrast the first men:

these theological poets, unable to make use of understanding, did the opposite and more sublime thing: they attribute senses and passions ... to bodies, and to bodies as vast as sky, sea and earth. (Vico 1968:131)

In my research, I have been making deeper and deeper inquiries into the importance of the body in theology. In this regard I have proposed a model for theological anthropology as embodied sensing, a contemporary theological anthropology that functions within the intricate relationship of the lived body, experiencing and language with an openness to the 'more than', to that which lies beyond the boundaries of the skin (Meiring 2015:3 of 8). Perhaps it is another way of arguing for theologians, to once again become theological poets.

I want to focus on the turn towards the body in the corporeal-linguistic turn, the description of consciousness in the work of the neuroscientist, Antonio Damasio and more specifically on his theory of how the brain maps the body. In my own work as narrative theologian I have used bodymapping as an applied aspect of theological anthropology as embodied sensing, bordered by the

Note: Original Research: Volume 17 in the South African Science and Religion Forum Series, edited by Prof. Dr Cornel du Toit (UNISA) and Prof. Dr Danie Veldsman, entitled 'Creation, Consciousness and Christology: Evolutionary Perspectives', Proceedings of the 20th conference of the South African Science and Religion Forum (SASRF) of the Research Institute for Theology and Religion held at the University of South Africa, Pretoria 16-18 September 2015. 
tenets of narrative therapy. How does my use of bodymapping intersect with Damasio's body maps in the brain, if at all? I also want to explore the notion of sensing, as used in my model for theological anthropology, in the work of Damasio and in the carnal hermeneutics of the Irish philosopher Richard Kearney.

\section{The corporeal-linguistic turn}

One of the main features of a contemporary lifestyle is being occupied with the body; an entire industry exists that serves the needs for wholeness, beauty and salvation, which traditional religious institutions fail to satisfy (AmmichtQuinn 2004:72). This occupation with the body does not necessarily hail a defeat of the body-mind dualism. Maxine Sheets-Johnstone refers to the Cartesian legacy as a '350-yearold wound' that is still in need of healing and 'ironically, it is being reopened by reductionist thinking that collapses body into brain - the brain - thereby passing living reality' (SheetsJohnstone 2009:2). The turn away from the Cartesian dualism with its focus on the body-mind divide has, in certain disciplines, become a turn to and a fixation on the brain-mind or brain-consciousness debate, an equation which once again sidesteps the body and compounds the body into brain.

However, the occupation and even near obsession with the body in contemporary society does in a way illustrate the extent and the impact of the corporeal turn, which occurred in various disciplines during the 20th and 21st centuries. The challenge by feminism, postmodernism and critical theory to the Cartesian dualism happened as a result of the 'philosophical and social consequences of major transformations in the nature of society, primarily towards the emergence of a postmodern or information society' (Turner 1996:20). In a post-industrial society there is a 'strong commercial and consumerist interest in the body as a sign of the good life and an indicator of cultural capital' and that a society, which emphasises consummation, also focuses on the body beautiful, the rejection of death, a denial of the ageing body, and embracing the fit, sporting body (Turner 1996:2). The body has become especially important in industrially advanced societies where developments in medical technology and medical practice have changed the structure of disease and illness (Turner 1996:5). One of the social impacts of these changes includes a population with a significant number of retired, elderly and disabled people. This reality has an enormous impact on economic productivity and the way people spend their leisure time and money. These are some of the reasons why there was a turn to the body in humanities and social sciences 'as a consequence of these macro changes in the social, economic and legal status of human embodiment in a society of rapidly expanding technology' (Turner 1996:6).

In her book, The Corporeal Turn, Maxine Sheets-Johnstone (2009) argues that the humanities and human sciences were the breeding ground of the linguistic turn and the later corporeal turn, two fundamental conceptual shifts in the twentieth century. Each movement shifted the attention the use of language and the body, two phenomena that were taken for granted for a long time (Sheets-Johnstone 2009:2). The corporeal turn was not only about giving attention to something that was simply ignored, but correcting a centuries-old misrepresentation. Here she refers to the Cartesian legacy where the body was seen as inferior and subservient to the mind, or as she describes it 'as mere material handmaiden of an all-powerful mind, a necessary but ultimately discountable aspect of cognition, intelligence, and even affectivity' (Sheets-Johnstone 2009:2). Her description of the corporeal turn fits that of the historian, Judith Surkis who describes a turn not only in terms of a change in direction, but also as 'formative: they shape and reshape by cutting away' (Surkis 2012:704). She refers to Gabrielle Spiegel, who argues that a multitude of challenges arose after the Second World War with regard to the philosophical investigation of language, the anthropological exploration of culture, the psychoanalytical investigation of subject formation, and the limits and possibilities of the formation of knowledge. The generation who came of age in the 1960s and 1970s posed further questions that resulted in the various 'turns', including the linguistic and corporeal turns, which lead to 'a massive change in our understanding of the nature of historical reality' (Surkis 2012:703). She also refers to Martin Jay, who writes about several 'linguistic turns'; it begins with language philosophy as influenced by Wittgenstein and the later German hermeneutical tradition, and could be subdivided into the existentialist tradition (Gadamer) and the critical theory tradition (Habermas). She concludes that the linguistic turn and other 'turns' could be 'better understood not as historically inevitable disciplinary trajectories, but as specifically located, imaginatively cast, at once multiple, overlapping, and dynamically constellations' (Surkis 2012:706). Hans Ruthrof, professor of English and Comparative Literature, talks about the transition in a literary environment from a 'linguistic turn' during the 20th century to a 'corporeal turn' in the beginning of the 21st century. He makes the claim that 'the body is reclaiming its central place in evolution, especially in such evolutionary products as language and the human imagination' (Ruthrof 2000:34). He also marks the priority of the non-verbal and argues that even after thousands of years, language still keeps its 'epistemic, iconic perspective of the body' in describing the world with our bodies as the human scale (Ruthrof 2000:38).

Sheets-Johnstone views the corporeal turn as far from complete and envisions the corporeal turn as:

an ever-expanding, continuous, and open-ended spiral of inquiry in which deeper and deeper understandings are forged, understandings that in each instance themselves call out for deeper and deeper inquiries. (Sheets-Johnstone 2009:1)

This dedicated examination requires an openness to interdisciplinary investigations and the disciplines she links in her research hold the body as foundation and 'testify to the rich and complex dimensions of bodily being' and that such interdisciplinary research: 
attest(s) to the importance of exploring the living realities of corporeal life and of understanding in the deepest sense in each instance what it means to be the bodies we are. (SheetsJohnstone 2009:3)

She claims that 'to meet the challenge of languaging' dynamic experience 'is to be true to the truths of the experience'. These dynamic experiences refer to the 'complex diversity of feelings and thoughts that exceed the bounds of everyday language because they are experienced dynamically'. She proposes a methodology along phenomenological lines that 'demands our drawing back from an easy, ready-made everyday language and our turning first of all to experience itself'. To be able to do this, she continues that we have to 'bracket' our natural attitude towards the world and 'thereby meet an experience as if for the first time' (Sheets-Johnstone 2009:378). She understands the notion of bracketing as a process where everyday judgements, beliefs and reactions are put aside, as well as 'everyday habits of languaging experience'; in doing this, experience itself is moved to the foreground and we can listen to its interior dynamics. She refers to Husserl's phrase 'for all this, names are lacking' in emphasising the need to first experience the dynamics before trying to describe or name them. She writes that 'names are indeed lacking not only because everyday language is basically deficient with respect to dynamics, but because names cannot do justice to dynamics'. Emotions have a double dynamic in the sense that they 'move through us in distinctive ways and move us to move in distinctive ways'. We experience cognitive emotions in feeling fear, sadness and delight, where a 'felt dynamic moves through our bodies and moves us to move - or not to move - in an affectively unique manner' (Sheets-Johnstone 2009:380).

Was there really something like a 'corporeal turn', a conceptual shift that happened some time during the 20th century? The Austrian-born philosopher, Ludwig Wittgenstein set in motion a linguistic turn, followed by several other linguistic turns in early 20th century, between the First and Second World Wars. Soon after, French philosophers and the phenomenological movement laid the foundation for the corporeal turn. The Second World War was the turning point, not only because of the scale of destruction and the enormous loss of human life, but also because of the advances in technology stimulated by the weapon industry, aviation and espionage. The atrocities committed during this war, the images of destruction, and of dead, tortured and emaciated bodies were captured in photos and on film reels and broadcasted in cinemas and in newspapers. French philosophers, such as Maurice Merleau-Ponty (1945), Gabriel Marcel (1951) and Michel Foucault (1954) put the body at the centre of the ontological problem and in this way, initiated the corporeal turn. The work of Merleau-Ponty was especially influential, and with the translation of his book, Phenomenology of Perception (1962) into English, he reached a much wider audience in the United Kingdom and across the Atlantic Ocean as far as North America. The influence of his ideas is very clear in the humanities and social sciences, especially in sociology, philosophy, psychology and anthropology. I would agree with the description of the historian Gabrielle Spiegel that the generation who was born during or after the Second World War and who came of age in the 1960s and 1970s asked further questions that resulted in more 'turns'. Norbert Elias (1969) was one of the first academics to carry the corporeal turn into sociology with his analysis of the civilised body (Meiring 2014:79). The 1960s and 1970s were also the decades when great value was placed on the body in social life; in the 1980s, feminist theology, black theology, liberation theology and queer theories had a further impact on the social regulation and construction of the bodies of women, black people, impoverished people, and of gay men and lesbian women. The HIV and AIDS epidemic which raised its head in the 1980s also had an impact on perceptions of the healthy or diseased body, of intercorporeal contact and relationships, as well as perceptions along the line of the touchables or untouchables. Humanistic psychology, developed in the 1960s, laid the foundation for the emergence of somatic psychology in the 1970s and 1980s with an emphasis on the body as subject that determines the method of inquiry. The application of body-mind therapies within somatic psychology was greatly influenced by the cultural changes of the 1960s, as well as the influx of people and Asian wisdom into the West, with for example Tibetan refugees settling in Europe and North America after the annexation of Tibet by China in 1949.

Scanning literature in disciplines like philosophy, sociology, somatic psychology, palaeoanthropology, cognitive science and anthropology (which is in no way exhaustive), one can trace the corporeal turn (Meiring 2014:80). The work of the post-war French philosophers appeared in the late 1940s, early 1950s and in translations in the 1960s. Academic publications in other disciplines appeared in the late 1970s and early 1980s, with a lull in the 1980s; in the 1990s, and especially in the last years of this decade there has been a surge in publications on the body and embodiment. My own argument would be that one could refer in broad terms to the corporeal turn (1940-1965), followed by a second wave (1976-1986), and a third wave (1990-2000). Perhaps it would also be feasible to speak of second and third generation corporeal turns. The second generation corporeal turn appears to be a tentative application of the insights from the post-war French philosophers in other disciplines like sociology, psychology and theology. It also seems that it had a limited interdisciplinary scope. From research done within cognitive science, I note a third generation corporeal turn with a striking feature that points to a convergence of the linguistic and corporeal turn, also as a result of cognitive linguistics with an emphasis on how language develops from the body, and the influence of metaphorical thinking. I would refer to this third generation corporeal turn as a corporeallinguistic turn. Once again, philosophy has set the pace with the work of authors like Eugene Gendlin, Thinking Beyond Patterns: Body, Language, and Situations (1991), George Lakoff and Mark Johnson, Philosophy in the Flesh (1999), and Horst Ruthrof, The Body in Language (2000). Paleonanthropology 
also expressed this awareness of the origin of language and bipedality (the ability to walk upright). The 'Roots' series of Maxine Sheets-Johnstone (1990, 1994, 2008) also had a wide influence and her research crossed the divide between philosophy, palaeoanthropology, and evolutionary biology with a special emphasis on the tactile-kinaesthetic body. She developed a 'hermeneutics of the body', which placed the focus on the crucial role of the human body in understanding and meaning. One of the outstanding features of this third generation corporeal-linguistic turn is a wider interdisciplinary inquiry with a special focus on the insights from cognitive science and molecular biology (Meiring 2014:81).

The question can then be explored of how the corporeal turn manifests in theology and more specifically in theological anthropology. In the 20th century, body theology (as initiated by James B. Nelson in the late 1970s) and theology of the body (as expounded by Pope John Paul II in the early 1980s) introduced the crucial notion of the body and bodily experiences into theology as a significant correction to Cartesian dualism. Theology was at the forefront of incorporating the corporeal turn, even when compared to many other academic disciplines. The body became a contentious topic in the church of the twentieth and twentyfirst centuries in the wake of the sexual revolution that was sparked by, among others, the work of Wilhelm Reich in the 1930s. This revolution reached its culmination in the 1960s, 1970s and early 1980s when its momentum was stumped by social, economic and political factors - the HIV and AIDS epidemic being one of them (Meiring 2014:211). Liberation theology introduced many enquiries into issues of race, poverty, power structures in society, gender and heterosexism, sexual orientation, and ecology into body theology.

Both Nelson's body theology, and Pope John Paul II's theology of the body developed as an effort to rectify the impact of the Cartesian dualism; it developed in reaction to the sexual revolution, with both using, for example, homosexuality as a test case. Nelson's body theology was at first coined as a sexual theology with an extensive focus on human sexuality. He developed his body theology as a Christian ethicist, implying that his body theology does not, therefore, have a deep grounding in any specific doctrine. The limitation of body theology and theology of the body is that it primarily remains focused on issues of human sexuality and confines their profound insights to Christian ethics or moral theology.

Pope John Paul II developed his thoughts on a theology of the body as systematic theologian and philosopher, and although it entails a systematic discussion of concepts, such as original solitude, original unity, original nakedness, original shame, the spousal meaning of the body, the resurrection of the body, the mystery of spousal love, and the discussion of ethical problems, its main purpose is the defence of Humanae Vitae - the unitive and procreative meaning of the conjugal act within the divine plan for human love as 'an adequate anthropology'. Humanae Vitae is considered to be the specific moral application of this adequate anthropology in married life, with a special focus on the question of contraception. The beauty of sex can never be separated from the profound spousal meaning of the body. The pope's theology of the body easily finds a home in moral theology, as does the body theology of Nelson, which remains confined to Christian ethics (Meiring 2014:273).

A transition should be made from primary theology to secondary theology, and this is where theological anthropology provides a wider and deeper conceptual basis for enquiries and reflections on the body in theology. It can incorporate the insights from other disciplines, from body theology and theology of the body, as well as the different voices from the history of Christianity and concrete life-worlds. I can but only agree with David Kelsey's assessment that theological anthropology is 'the point at which Christian and secular thought most easily and immediately engage each other in the service and also practices within the common life of pluralistic culture' with the most direct bearing on practical life (Kelsey 2009:7).

I have discovered in the theological anthropology of David Kelsey a contemporary theological anthropology that has a certain understanding of the textures of life and a sentiment of the flesh, one that consistently uses the body as an organising principle.

In part one, Created: Living on Borrowed Breath he answers the question on what humans are by way of a theology of birth (reading the narrative of having been born as a living body in tandem with being given a living body by God); developing the notion of a personal living body (God personalises human creatures) and putting forward the idea of flourishing bodies (humans flourish by being wise in the here-and-now quotidian world). In part two, Consummated: Living on Borrowed Time he explores the continuity and dramatic discontinuity between the pre- and post-Easter body of Jesus. He also develops the notion of 'eschatologically fully consummated living human personal bodies' where he sets out what he coherently conceives glorified bodies to be.

In part three, Reconciled: Living by Another's Death he holds that humans are reconciled and eschatologically consummated through the bodily actions of Jesus as human creature, where he enacts his own creaturely being as a living human personal body. God relates to humans through the incarnation of Jesus who is 'as one amongst us at once both our ultimate and proximate contexts' (Kelsey 2009:609). He describes the theocentric portrayal of human existence in his theological anthropology as 'a whole-in-complexity' (Kelsey 2009:900). His theological anthropology is a radical break from conventional Christian anthropology that uses the imago Dei as organising principle and as the fundamental feature that distinguishes humans from animals and makes them distinctively human. Kelsey only introduces the concept of imago Dei in the codas at the end of his book, where he offers 
a Christological interpretation of the imago Dei, whereby the image of God is the concrete person of Jesus Christ and not some general property that humans possess in contrast to other non-human creatures. Jesus Christ is the 'imager of God in his humanity' and is the 'grammatical paradigm' of human being (Kelsey 2009:1009). Humans, as finite living mysteries that image the triune living mystery are the 'imagers of the image of God'.

In a way Kelsey's theological anthropology can be applied as a 'template' for theological anthropology, one that is open to the insights from other disciplines, including both social sciences and natural sciences, even though that is not what it endeavours to be. His theological anthropology is an important correction to the 'value anthropocentrism' of premodern (and some late modern) Christian theological anthropologies based on their interpretation of the notion of imago Dei, whereby humans are considered to be more important that other non-human creatures, also by focussing on the rational soul and by denigrating the physical body (McDougal 2011:57). The proposals in Kelsey's theological anthropology is a 'conceptual compass' enabling theological anthropology to stay on course without being normative in claiming that this is the way to do theological anthropology (McDougal 2011:70). Kelsey wants to indicate a theological direction with a certain practical wisdom. But to what extend does he take note of and incorporate the corporeal-linguistic turn in his theological anthropology? It is clear from his work that he has taken extensive note of the developments in evolutionary biology, for example in his description of eschatologically consummated personal bodies, and his refusal to accept the fall of anyone like Adam and Eve in the light of evolution and the origin of all living species. He also refers to the insights from psychology, although he is sceptical of applying psychological evaluations of personhood and human characteristics to a theological notion of personhood or his concept of personal bodies.

Kelsey is, however, quite frank that although theological anthropology could be an exercise in 'conceptual bridge building' with other 'strategically selected secular conversation partners' from anthropological wisdom and appropriate sciences, as well as different religious traditions, his theological anthropology deliberately focuses on the 'theological end of the bridge' (Kelsey 2009:7). He also recognises the importance of issues such as race, gender and sex as part of the human's 'quotidian personal identities', but considers these to be topics for another time and another project (Kelsey 2009:80). Kelsey's theological anthropology does integrate this corporeal-linguistic turn, although not as extensively as it could, mainly because of its explicitly stated focus on the theological end of the interdisciplinary bridge. This leaves 'clearings' in his theological anthropology that gives rise to the opportunity for filling these clearings through insights gained from various disciplines where a deeper understanding of the body has been developed (as captured in the corporeallinguistic turn), as well as other contemporary theological anthropologies that have incorporated ideas of the body and embodiment.

Kelsey does not pay much attention in his theological anthropology to bodily experiences and leaves another clearing in his theological anthropology for the integration of bodily experiences as a source of revelation and knowledge. His focus is rather on the wise practices of humans in their interaction with other humans, non-human creatures, and social institutions, with humans being the social, intentional, bodied enactors of these complex practices. Being given a living body by God makes them accountable to God for their bodied response to God. His viewpoint is that God calls us to be wise, and our appropriate response is faith, where faith is understood as 'wise human action in the quotidian for its well-being for its own sake' (Kelsey 2009:310). Kelsey himself does portray his theological anthropology as a relentless exercise in secondary theology, where secondary theology is more concerned with the critical reflection on received authoritative theological traditions, and attempts to put new formulations of theological themes forward to which primary theology can appeal and respond. Primary theology is very concrete and analytical, and is used in the expression of the communal practices of Christian communities, such as prayer, liturgy, ethical analysis and moral judging. The appeal to experience in body theology (as influenced by liberation and feminist theology) can be interpreted as an outflow of primary theology. The challenge, however, is to incorporate experience as a source of revelation into theological anthropology as secondary theology.

The model for theological anthropology as embodied sensing endeavours to fill in and expand these clearings in Kelsey's theological anthropology, based on an interdisciplinary enquiry into the body and embodiment as well as an exploration of notion of embodied sensing, also through the use of bodymapping as a research tool.

\section{Consciousness in the work of Antonio Damasio}

Antonio Damasio developed a two-part hypothesis on consciousness. The first is that the brain constructs consciousness and does so by creating a process of self within a mind that is awake. Wakefulness and mind are the two crucial components of consciousness, but the self is a separate element. He describes the essence of the self as 'a focussing of the material organism that it inhabits' (Damasio 2012:180). The second part of the hypothesis is that the self is constructed in stages. The protoself is built at the most basic stage and emerges from the part of the brain that gathers images describing the stable aspects of the body and generates primordial feelings of the living body. The core self emerges during the second stage when an interaction between the organism and an object-to-be-known modifies the protoself as well as the image of the object (Damasio 2012:181). Some of these modified images are known as feelings. When multiple objects, also recorded as lived experiences or an anticipated 
future, interact with the protoself, they produce a profusion of core self pulses allowing the autobiographical self to emerge in the third stage. All these selves are constructed in separate, but coordinated 'workspaces' in the brain (Damasio 2012:181).

Damasio's research has indicated that although consciousness does not reside in a centre of the brain, it is predominantly assembled 'in the image spaces of early cortical regions and the upper brain stem', the so-called 'performance space' (Damasio 2012:241). He argues that the neurology of consciousness is centred on structures in the brain that generate wakefulness, mind and self. The brain stem, thalamus and cerebral cortex are primarily involved with each component of the triad, but all of them contribute to certain aspects of wakefulness, mind and self (Damasio 2012:243).

Self is not a thing. It's a process, and it is from this perspective that Damasio (2012:8) makes the distinction between self as a dynamic object and self as knower (focussing on experience and our reflection on that experience). He defines selfas-object as 'a dynamic collection of integrated neural processes, centred on the representation of the living body, that finds expression in a dynamic collection of integrated mental processes'. The self-as-subject (the knower) builds upon the self-as-object, not as an opposite but as a continuation, which he describes 'as not only a very real presence, but a turning point in evolution' (Damasio 2012:9). He cautions against mind as a non-physical phenomenon 'discontinuous with the biology that creates and sustains it' (Damasio 2012:14). The insights from evolutionary biology and neurobiology demand us to consider the gradual development from early living organisms across evolutionary history to current organisms; the slow modifications of nervous systems linked to the gradual emergence of behaviour, mind and self (Damasio 2012:16). Consciousness began with the emergence of a protagonist (the self, me or I) capable of bearing witness, and only when brains developed language, did mind come into existence (Damasio 2012:17).

In his earlier book, The Feeling of What Happens: Body and Emotion in the Making of Consciousness, Damasio (1999:37) makes the observation that 'life needs a boundary'. This implies that life can only be transmitted within a certain boundary, which is a body. He believes that 'minds and consciousness, when they eventually appeared in evolution, were first and foremost about life and the life urge within a boundary' (Damasio 1999:37). The two crucial achievements of consciousness are the managing of life and the safekeeping of life (Damasio 2012:25). He argues that the conscious mind emerged within the history of life regulation, a process called homeostasis. Briefly explained, it starts with unicellular living creatures, for example, an amoeba who has no brain, but can adapt its behaviour. Then it progresses to organisms whose simple brains can manage behaviour (e.g. worms). From there it progresses to organisms whose brains generate behaviour and mind (e.g. fish). With the generation of primordial feelings, an early form of sentience emerges and then a process of self-organisation develops, which constitutes the beginning of elaborate conscious minds (e.g. reptiles and birds). For most species, the self emerges at a core level. Humans (and other mammals e.g. apes, elephants, marine mammals) have both a core and autobiographical self. (Damasio 2012:26). With the evolution of mammals, especially primates, minds became more complex and part of our mind became capable of monitoring other parts of the mind's operation. He describes it as follows:

The conscious minds of humans, armed with such complex selves and supported by even greater capabilities of memory, reasoning, and language, engender the instruments of culture and open the way into new means of homeostasis at the level of societies and culture. In an extraordinary leap, homeostasis acquires and extension into the sociocultural space. Justice systems, economic and political organisation, the arts, medicine, and technology are examples of the new devices of regulation. (Damasio 2012:26)

Religion is surely another example that we could add to this new devices of regulation. The goal of basic and sociocultural homeostasis is the survival of living organisms in a variety of ecological niches, but in the case of sociocultural homeostasis, it also entails the deliberate seeking of well-being (Damasio 2012:27).

\section{The creation of maps in the human brain}

Damasio reaffirms his conviction of the notion that 'the body is a foundation of the conscious mind' with his hypothesis on the mapping of the body in the brain (Damasio 2012:20). Although homeostasis is a primary function of the human brain, its distinctive feature is the ability to create maps. Mapping and homeostasis functions in tandem and through the ability of the brain to make maps, the brain informs itself (Damasio 2012:63). Maps create images and that is the main currency of human minds. Damasio continues that 'ultimately consciousness allows us to experience maps as images, to manipulate those images, and to apply reasoning to them'. Maps result as an interaction with objects and in this way 'action and maps, movement and mind, are part of an unending circle' (Damasio 2012:64). The creation of maps in the brain is a never-ending process with the brain mapping every object and action outside of it. With the term image, Damasio refers to a mental pattern or mental image and with map or neural pattern, he indicates a pattern of activity in the brain, distinct from mind (Damasio 2012:65).

It is important to note that these maps are not static, but that brain maps are always in flux, changing from moment to moment as it reflects the changes happening in the neurons that feed these maps. These changes in the neurons echo the changes in the outside world as well as inside the body, also taking into consideration the body that is in constant motion (Damasio 2012:67). It is not only visual patterns that are being mapped, but all kinds of sensory patterns. It processes patterns with regard to body structures (e.g. limb movements), touching, shape and texture (Damasio 2012:69). 
A consequence of the brain's constant mapping is the mind. The images in our minds of sounds, tastes, sights, touches, smells, pleasure and pains, the physical characteristics of entities and their spatial and temporal relationship, are the 'brain's momentary maps of everything and anything, inside our body and around it, concrete as well as abstract, actual or previously recorded in memory' (Damasio 2012:70). In this way, minds are 'a subtle flowing combination of actual images and recalled images, in ever-changing proportions', moving along in concurrent, parallel and sometimes superimposed sequences (Damasio 2012:71).

How does the brain map the body? Damasio argues that 'map-making brains' have the ability of literally introducing the body as content to the mind. The body never loses contact with the brain that maps it. The body-to-brain connection has to do with homeostasis, and managing life is about managing a body. Whatever is represented in the world outside the body, can only come into the brain via the surface of the body. The brain can only be informed through the body (Damasio 2012:89). By mapping the body in a coherent manner, the brain lays the foundation of what will become the self. The intimate relationship between body and brain is also essential in comprehending spontaneous bodily feelings and emotions.

Damasio describes the body and brain as being engaged in 'a continuous interactive dance' (Damasio 2012:96). The body sends neural and chemical messages to the brain. Interoception refers to the complex mapping of the interior sense of the body where chemical information is send via the bloodstream and neural messages are sent through nerve-fibre types from every part of the body to the central nervous system and along the vertical spinal cord length (Damasio 2012:96). Exteroception refers to messages send to the brain from skeletal muscles and the result of all this signalling, is 'a multidimensional picture of the body in the brain and, thus, in the mind' (Damasio 2012:97). The brain also communicates to the body through chemical (involving hormones) and neural channels. Through this interactive dance, 'thoughts implemented in the brain can induce emotional states that are implemented in the body, whereas the body can change the brain's landscape and thus substrata for thoughts' (Damasio 2012:96).

States in the brain cause certain body states to appear, which are then mapped in the brain and assimilated into ongoing mental states. How these body states become bodily feelings is integral to the understanding of the conscious mind (Damasio 2012:101). The brain has the ability to construct maps of the body as if the body has indeed been changed by a certain emotion, in such a way that the construction takes place instead of the actual emotions. In his earlier work, Damasio (1999:281) refers to this as the 'as if body loop'. Changes are created in sensory body maps 'as if' the body has been changed, even if it has not. He has found more support for his hypothesis in the discovery of mirror neurons as the 'ultimate as-if body device' (Damasio 2012:103).
The simulation of a body state occurs in the body maps even though it is not actually taking place. This explains the role that mirror neurons can play in enabling us to understand the actions of others by placing ourselves in a similar body state (Damasio 2012:104) which is associated with the role of empathy. Damasio summarises the process of bodymapping in the brain as follows:

The living body is the central locus. Life regulation is the need and motivation. Brain mapping is the enabler, the engine that transforms plain life regulation into minded regulation and, eventually, into consciously minded regulation. (Damasio 2012:107)

\section{Bodymapping and theological anthropology}

I have appropriated the use of body maps as a full-scale map drawn of the body in my work as narrative theologian and as a research tool within theological anthropology and refer to in this context as bodymapping. The use of body maps originated in Khayelitsha, Cape Town, in 2002 where the University of Cape Town start running Memory Box workshops (Meiring 2015:6 of 8). Memory work is used with people living with HIV or AIDS helping them to prepare for their own deaths and leaving their story behind for their children. In these workshops, facilitators discovered that people who were undergoing antiretroviral therapy (ART) treatment, were more future orientated than looking at the past. A large group of people had begun to draw their life stories, hoping to live longer. Flowing from this discovery, Jonathan Morgan and Jane Solomon developed the bodymapping process. Jane Solomon describes bodymapping as a way of telling stories and making art about a person and their life (Solomon 2007:2-3).

I have framed bodymapping within the tenets of narrative therapy and the narrative metaphor. The narrative therapists, Jill Freedman and Gene Combs describe the narrative metaphor as follows:

Stories inform life. They hold us together and keep us apart. We inhabit the great stories of our culture. We live through stories. We are lived by stories of our race and place. Whatever culture we belong to, its narratives have influenced us to ascribe certain meanings to particular life events and to treat others as relatively meaningless. Each remembered event constitutes a story which together with our stories constitute a life narrative, and, experientially speaking, our life narrative is our life. (Freedman \& Combs 1996:32)

The narrative metaphor gives ample space for the development of practices that are 'non-normative'; practices that do not unquestionably reproduce and simply reinforce the norms of mainstream culture. Through the 're-authoring' of conversations people can attach new meaning to events that have been neglected in the past and to connect these with 'other events of their lives in sequence that unfold through time according to alternative themes ... the counter plots of their lives' (White 2011:6). The unpacking of 
narratives is a way to deconstruct negative identities linked to cultural stories, but it also opens the way of thinking and living about these stories, 'the historical and cultural ways of being in the world and thinking about the world that these stories are bearers of' (White 2011:8).

The bodymapping process in short entails that a client or coresearcher draw a full-scale map of their body, using colour, symbols and metaphors to recount the stories that are written on their bodies and 'inside' their bodies (see Figure 1). I also view bodymapping as an applied aspect of theological anthropology as embodied sensing and careful attention is paid to how words or language works in the body, how the 'unsaid' is expressed. The bodily experience of a particular person in concrete life-world is explored and the lived body is taken seriously as a site of knowledge and resistance against dominant metanarratives, also in the way it is spatially sensed as well as the influence of physiological factors. The 'more than' in this context is often expressed in metanarratives about religion and God.

In previous research I have found dominant themes which surfaced around acceptance and rejection, connected to concepts of heaven and hell resulting in strong feelings of guilt, especially regarding sexuality and bodiliness. This is in turn manifested in the body by way of eating disorders, stress, sexually alienating behaviour and dissociation from the body (Meiring 2015:7 of 8). Experiences of rejection were also linked to extremely dominant metanarratives of what it means to be a good wife, a good mother, a pretty woman, an attractive man, the typical male. The language of these metanarratives is grounded in that of a patriarchal heterosexism. My impression was that it causes a lot of anxiety and confusion regarding personal identity. These same patriarchal heterosexist metanarratives had an almost unbreakable hold on male and female clients' image of God as purely male (Meiring 2015:8 of 8). Bodymapping is a powerful medium to create awareness regarding dominant sociocultural metanarratives and can be used to facilitate a process of body integration.

The question is whether there is an intersection between Damasio's hypothesis on how the brain maps the body and bodymapping as a way of storying experiences and perhaps body states? In trying to explore this, I want to turn to how the notion of sensing is used in my model for theological anthropology as embodied sensing, as well as in the work of Antonio Damasio and the Irish philosopher, Richard Kearney.

\section{On sensing}

Damasio uses 'sensing' within the context of homeostasis, where the unconscious urge to stay alive is expressed inside a simple cell by 'sensing' the state of the chemical profile inside the boundary, a kind of 'unconscious knowledge' of what to do chemically when there is a lack or surplus of some ingredient at some place or time within a cell (Damasio 1999:138).

My own rendering of sensing as embodied sensing was inspired by the body theology of James Nelson who makes the assertion in his 1978 book that 'body theology begins with the concrete' and not with doctrines or creeds or problems in tradition (Meiring 2015:3 of 8). It begins with the concrete and 'the fleshly experience of life - with our hungers and our passions, our bodily aliveness and deadness' (Nelson 1992:43). He considers 'lived experience' to be the most neglected in theology. Nelson writes that for many, theology is a 'second moment' and that the first moment is 'life itself', that 'theology comes afterward, attempting to understand and serve life' (Nelson 2004:57).

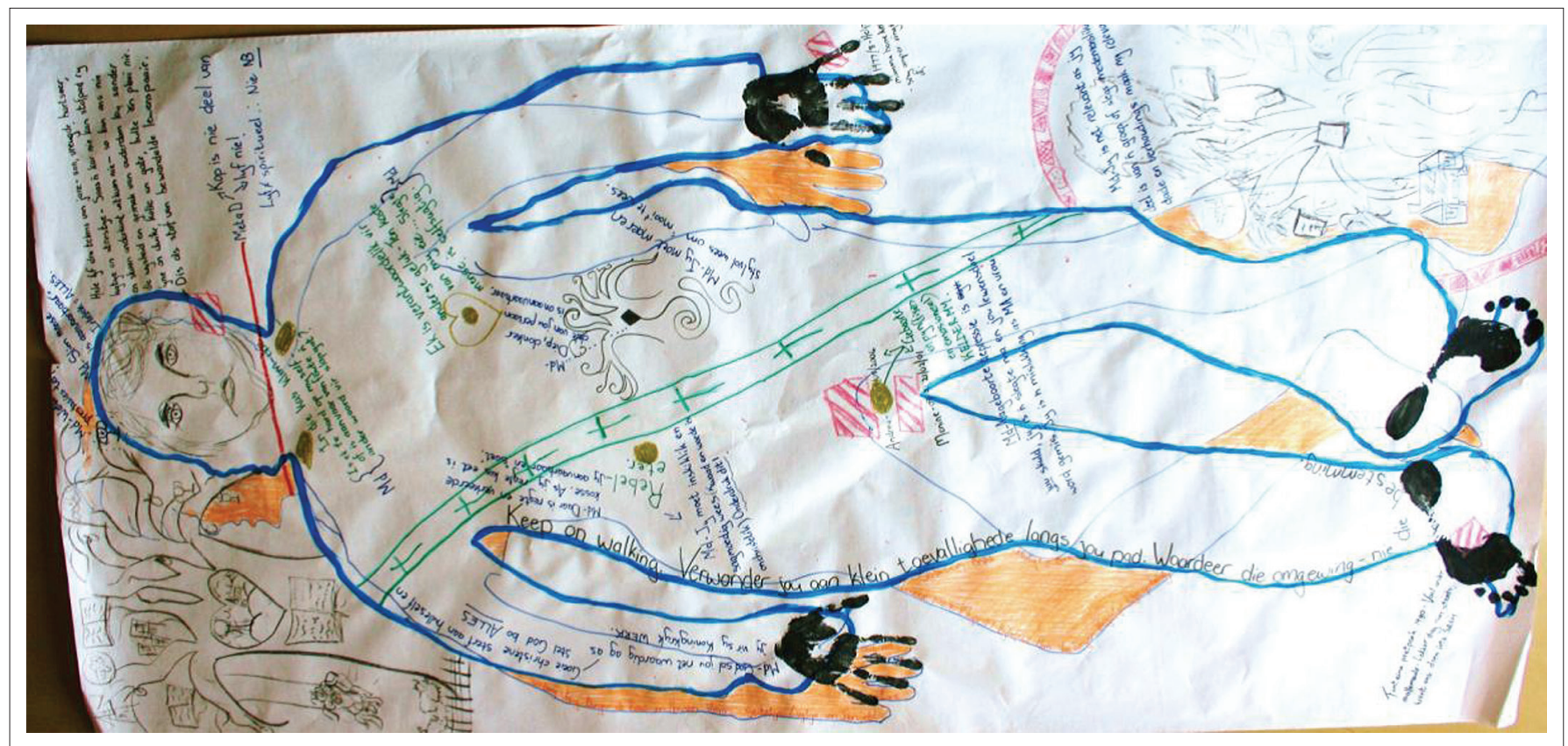

FIGURE 1: Body map of co-researcher (Meiring 2014:57). 
It was influenced by the book of George Lakoff and Mark Johnson (1999), Philosophy in the Flesh. They define 'philosophy in the flesh' as 'a way to know ourselves better, to see how our physical being - flesh, blood, and sinew, hormone, cell, and synapse - and all things we encounter daily in the world make us who we are' (Lakoff \& Johnson 1999:568). Their philosophy in the flesh also builds upon the insights of cognitive science with its research on notions of concepts, language, reason and feeling and in doing so, they promote a conversation between philosophy and cognitive science; they view the latter as one of the most significant resources for self-knowledge.

It was influenced by the work of Maurice Merleau-Ponty, who wrote about the body as 'a vehicle of being in the world and having a body is, for a living creature, to be involved in a definite environment, to identify oneself with certain projects and be continually committed to them' (Meiring 2014:21). It was deeply inspired by the work of language philosopher and psychologist, Eugene Gendlin who asserts that 'experiencing is inherently sense-making', and that sensemaking is implicitly symbolised in the interactional events with other human and non-human creatures (Gendlin 1997:32). These events are then elaborated through language which Gendlin refers to as 'eventing' (Meiring 2015:5 of 8).

The term 'sensing' also endeavours to capture what Gendlin conveys with the word 'focussing' and Les Todres with the expression 'embodied understanding'. Todres defines 'embodied understanding' as 'a form of knowing that evokes the possibility of living, bodily relevant textures and meanings' (Todres 2011:2). He in turn builds upon Gendlin's notion of focussing, which is about paying attention to the words that work, responding to an experience where language captures the felt sense of a word in the body. It is a focus on texture where a phenomenon is not merely a theoretical description of an occurrence, but a live moment that was embodied by a person in a concrete situation.

It is furthermore an effort to express the notions of sentiment of the flesh and sensitivity to the textures of life. David Kelsey alludes to the 'textures of life' when he refers to the created proximate context as 'humankind's lived world in its concrete everydayness', and the dignity that is inherent to this everydayness, where the perfect, real and authentic human is the 'ordinary everyday human person' (Kelsey 2009:162). He alludes to the 'textures of a fleshly world' when he sees the proximate context as 'inherently ambiguous' - filled with 'the possibility of our well-being' as humans and at the same time holding the potential of pain, loss and death (Kelsey 2009:201). Embodied sensing is then a move away from a pure cognitive, objective approach and is derived from the Latin word sensus, which expresses the faculty of thought, feeling and meaning all in one (Meiring 2015:4 of 8).

I was pleasantly surprised when I encountered the same sentiment in the recent book, Carnal Hermeneutics, edited by Richard Kearney and Brian Treanor (2015). For them, carnal hermeneutics provides a philosophical approach to 'the body as interpretation', trying to answer the questions of how we make sense 'of bodies with our bodies' and how to 'read between the lines of flesh and skin' (Kearney \& Treanor 2015:1). Their hermeneutical project endeavours to 'go all the way down' and to abandon 'residual tendencies to oppose language to sensibility, word to flesh, text to body' and to realise that 'all experience, from birth to death, is mediated by our embodiment and only makes sense of sense accordingly' (Kearney \& Treanor 2015:2). The challenges for the ongoing project of carnal hermeneutics, are what they call 'a radical commitment' to interdisciplinary dialogue (with disciplines like linguistics, theology, poetics, anthropology, politics and psychoanalysis) and to rethink the enigma of flesh'. This implies that 'flesh' cannot be reduced to a phenomenological version of the body, but should be recognised as a medium that connects humans to 'the flesh of the world'. Kearney states that his constant intention is to demonstrate 'how carnal phenomenology is intimately and ultimately carnal hermeneutics' (Kearney 2015:19). They then refer to flesh as 'the edge' where a human meets 'worlds that exceed and entreat it - animal and environmental, sacred and profane' (Kearney \& Treanor 2015:11).

Kearney uses 'sense' in three ways: first as the physical sensation of smell, taste, sight and touch. Then in connotation to meaning (to get the drift of what someone is saying); and lastly in reference of direction - 'how we orient ourselves in space and time, how we move toward or away from ...' All three connotations indicate how humans make sense of their lives in the flesh (Kearney 2015:15-16). There is a 'sensing in sense'. A person makes sense and receives sense from someone of something else that is not him or herself and it is flesh that 'mediates this otherness', shifting between self and strangeness (Kearney 2015:20). Because touch involves mediation, 'all our sensations involves interpretation' (Kearney 2015:20).

For Kearney, hermeneutics begins in the flesh. This is a correction to the 'hermeneutic turn' of the 1960s under the influence of Ricoeur's 'Conflict of interpretation' and Gadamer's 'Truth and method' where language was prioritised above the body. Kearney describes it as a 'journey from flesh to text' with the linguistic turn of hermeneutics 'departing from the carnal as a site of meaning' (Kearney 2015:16). Through the notion of carnal hermeneutics, he wants to 'revisit the deep and inextricable relationship between sensation and interpretation' because we are constantly 'reading the flesh, making sense of sensibility, and discerning bodies in lived passion and place even as we symbolise and dream' (Kearney 2015:17).

He places special emphasis on touch, with flesh as the medium. To touch and to be touched is to be connected with others in a way that makes us vulnerable. Through touch we are constantly exposed to the world around us, to life. To be in touch with flesh, is to be at risk and 'without risk no life is worth living' (Kearney 2015:24). He equates risk with the 'hermeneutic wagering of the flesh' (Kearney 2015:22) 
because there would be no originality to touch or tact without the sensitivity of touch, which exposes us and renders us fragile and naked. Touch is a simultaneous expression of body and soul, which implies that one cannot live without sensing, that a person 'cannot exist as soul without flesh' (Kearney 2015:23). Kearney understands touch as navigating a certain interval or gap that flesh is harbouring, that touch 'is not fusion but mediation through flesh' (Kearney 2015:19). Flesh (as medium) is 'the site where we are most keenly attentive to wound and scars, to preconscious memories and traumas, as even our navel reminds us' (Kearney 2015:22).

Kearney builds upon Aristotle's notion of flesh as metaxu (medium), acting as a transmitter between the senses and material objects, 'allowing the forms to travel to the soul', bringing the perceived and perceiver into communion, but never in direct contact (Kearney 2015:25). A gap or spacing is left between the organ and object. That is why he considers flesh as transmission and not as fusion. He interprets Aristotle's conclusion that 'flesh is the medium of touch' (Kearney 2015:25) as flesh being a diaphanous spacing or gap where the sensing of differences are possible, bridging the self and other. The notion of embodied sensing in my model for a contemporary theological anthropology converges with Kearney's reading of 'flesh as medium'. This mediating as 'the operation of spacing itself' sometimes conceals itself and at other times 'serves to transmit between deep and surface messages, translating between inner wounds and outer scars, between secret and signs, ... [the] hermeneutic task ... in the art of deciphering flesh' (Kearney 2015:26). The use of bodymapping and its link with implicit memory or body consciousness (Meiring 2015:7 of 8), is but one effort to decipher flesh.

Edmund Husserl referred to the body-soul as 'flesh' when he wrote that 'all sensings pertain to my soul' (Kearney 2015:28). According to him, the body (Körper) can be a thing, a mere object amongst many objects or it can transform into a living incarnate Body (Leib) when it incorporates 'tactile sensations' (to touch and be touched) as flesh. Kearney interprets this by writing that 'we are not, in the first instance, cerebral sovereign egos but sensing incarnate bodies' (Kearney 2015:28). With regard to the intercorporeal, Husserl regards the lived experience of other's bodies as an object out 'there' as Körper and as a living body like mine 'here' as Leib. In this way, 'flesh is the source of both our empathy and enmity with others' (Kearney 2015:29).

Merleau-Ponty revisits Husserl's notion of intertwining by reinterpreting flesh (la chair) 'as a mutual interweaving of perceiving and perceived', with flesh being a shared membrane between body and world. I 'exist my body' because I function 'in and from the flesh of the world' (Kearney 2015:38). Merleau-Ponty also gives an account of 'diacritical sensation' as a new mode of expressing a sensibility that lies in the crossing between sensation and language. Meaning is not construed through isolated objects or terms, but 'as parts of a mobile interaction of signs involving intervals. Absences, folds and gaps' (Kearney 2015:42). There is a gap in a level of meaning that is not related to an object. This relates to the structure of perception and is not merely a function of language. Kearney interprets diacritical perception through gaps as an indication of the inadequate correlation between consciousness and object. Merleau-Ponty insists that 'the sensing of meaning' is expressed through diacritical perception in these intervals, these gaps between our experiences and objects (Kearney 2015:43). Kearney reinterprets it as follows:

... perception operates like language in that it does not confront an object head on, but senses things which speaks to it laterally, on the side, provoking one's 'complicity' in the manner of an 'obsession'... the thing perceived 'solicits' us ... we are solicited by the flesh of the world before we read ourselves back into it. (Kearney 2015:45)

In Paul Ricoeur's book, Oneself as Another (1990), he defines flesh as 'the mediator between the self and a world which is itself taken in accordance with its variable degrees of practicability and so of foreignness' (Kearney 2015:51). We can only fully experience the human body if it is a body among others. A sense of our own individual belonging is provided by our experience of living in our flesh. According to Ricoeur, flesh is the place we exist in the world as both suffering and acting. But flesh is also a paradigm for otherness, that which is most mine and most other (Kearney 2015:51). Ricoeur's criticism of Husserl, is that his account of the flesh's intimacy to itself and its opening to the world through the mediation of others, was inadequate. Kearney puts it as Husserl having a carnal phenomenology, but lacking a carnal hermeneutics (Kearney 2015:53).

Kearney argues that to be able to empathise with others and to enter into an intersubjective world with others, one must have at the same time an intimate body for me (Leib) and a physical natural body among other bodies (Körper). This implicates a 'complex intertwining' where a person experiences him or herself as 'someone in a shared world'. There is no dichotomy between flesh and body (Kearney 2015:53). There will always be a gap, a distance between 'your body over there as flesh with my body here as flesh', implying that total assimilation is not possible (Kearney 2015:54). It is in this gap where hermeneutic mediation operates. Ricoeur speaks of 'a hermeneutic interpretation of the body by the body that precedes the work of inference through formal linguistic signs'. Kearney argues that this hermeneutic interpretation requires the special grammar of 'carnal hermeneutics, across distance, gaps, and differences: carnal hermeneutics as diacritical hermeneutics' (Kearney 2015:54). It is the realisation that flesh (as sensibility) should be combined with language in a new carnal hermeneutics (Kearney 2015:53).

\section{Concluding remarks}

Damasio speculates that the ultimate gift of consciousness to humanity is perhaps 'the ability to navigate the future in the seas of our imagination' (Damasio 2012:296). The reference to 
'the imagination of the first men' in Vico's work is not an effort to re-enter or re-create the non-verbal communication of those first men. Paul Ricoeur writes that 'primordial intuition' does not belong to this reading of indications (Damasio 2012:54). There is sufficient confluence between what I strive to achieve with the notion of embodied sensing and sensing in Kearney's carnal hermeneutics as diacritical hermeneutics (after Merleau-Ponty) to indicate that sensing here is an effort to find a grammar of the flesh, where flesh refers to the spacing between the intimate body and object. Kearney states that it is the task of carnal hermeneutics to find a balance between 'the movement of same towards other and other towards same' (Damasio 2012:55); a balance between body and flesh, between language and body. He then enquires about the kind of language we are talking about; 'one not only of words and writing, surely, but also of sensing and touching ... not only of intellectual "understanding but also of tangible orientation"' (Damasio 2012:55). The model for a contemporary theological anthropology as embodied sensing (the intricate relationship between language, the lived body, experiencing and the openness to 'the more than') is an effort to find this balance, to discover a grammar of the flesh. Together with bodymapping it is an imaginative effort on a practical and applied level to 'mind the gap', to find a grammar between the said and the unsaid, between the body and that which lies beyond the boundary of the body.

Based on Damasio's work on signalling (the intimate dance between body and brain, as hypothesised in the construction of body maps in the brain), it is reasonable to conceive that the embodied sensing of meaning (the reading of the gap between body and object through a grammar of the flesh), as expressed in bodymapping (within the context of theological anthropology as embodied sensing) and enriched by the notion of sensing in carnal hermeneutics, would in turn be mapped in the brain, with 'the body changing the brain's landscape and thus substrata for thoughts' (Damasio 2012:96) with subsequent alterations in the feelings of the body.

If the brain can only be informed through the body, and where Damasio holds that 'ultimately consciousness allows us to experience maps as images, to manipulate those images, and to apply reasoning to them' (Damasio 2012:54), it is reasonable to conceive that the embodied sensing of meaning could enhance the process of applying reasoning and meaning to images in the brain, perhaps even enhancing consciousness. This could be supported by Damasio's hypothesis that 'action and maps, movement and mind, are part of an unending circle' (Damasio 2012:54). I want to repeat Damasio's statement that the goal of basic and sociocultural homeostasis is the survival of living organisms in a variety of ecological niches, but in the case of sociocultural homeostasis, it also entails the deliberate seeking of wellbeing. I want to argue that theological anthropology as embodied sensing (including bodymapping) and carnal hermeneutics constitutes part of sociocultural homeostasis, expressing the embodied sensing of meaning; that by searching for a grammar of the flesh, it is consciously seeking for the well-being of living organisms and its worlds.

\section{Acknowledgements Competing interests}

The author declares that he has no financial or personal relationships which may have inappropriately influenced him in writing this article.

\section{References}

Ammicht-Quinn, R., 2004, 'Cult, culture and ambivalence: Images and imagination of the body in Christian traditions and contemporary lifestyles', in B. Baert (ed.), Fluid flesh. The body, religion and the visual art, pp. 67-81, Leuven University Press, Leuven.

Damasio, A., 1999, The feeling of what happens: Body and emotion in the making of consciousness, Houghton Mifflin Harcourt Publishing Company, New York.

Damasio, A., 2012, Self comes to mind: Constructing the conscious brain, Vintage Books, London.

Freedman, J. \& Combs, G., 1996, Narrative therapy: The social construction of preferred realities, W.W. Norton, New York.

Gendlin, E., 1991, Thinking Beyond Patterns: Body, Language, and Situations, Peter Lang Publishers, New York.

Gendlin, E., 1997, 'How philosophy cannot appeal to experience, and how it can', in D.M. Levin (ed.), Language beyond postmodernism: Saying and thinking in Gendlin's philosophy, p. 32, Northwestern University Press, Evanston, IL.

Kearney, R., 2015, 'The wager of carnal hermeneutics', in R. Kearny \& B. Treanor (eds.), Carnal hermeneutics, p. 18, Fordham University Press, New York.

Kearney, R. \& Treanor, B., 2015, 'Introduction: Carnal hermeneutics from head to foot', in R. Kearny \& B. Treanor (eds.), Carnal hermeneutics, p. 1, Fordham University Press, New York.

Kelsey, D., 2009, Eccentric existence: A theological anthropology. Volume 1 \& 2, Westminster John Knox Press, Louisville, KY.

Lakoff, G. \& Johnson, M., 1999, Philosophy in the flesh. The embodied mind and its challenge to Western thought, Basic Books, New York.

McDougal, J.A., 2011, 'A Trinitarian grammar of sin', Modern Theology 27(1), 55-71, http://dx.doi.org/10.1111/j.1468-0025.2010.01654.x

Meiring, J., 2014, 'Theology in the flesh: Exploring the corporeal turn from a southern African perspective', PhD thesis, Faculty of Theology, Vrije Universiteit, Amsterdam.

Meiring, J., 2015, 'Theology in the flesh - A model for theological anthropology as embodied sensing', HTS Teologiese Studies/Theological Studies 71(3), Art. \#2858, 8 pages. http://dx.doi.org/10.4102/hts.v71i3.2858

Nelson, J., 1992, Body theology, Westminster John Knox Press, Louisville, KY.

Nelson, J., 2004, Thirst: God and the alcoholic experience, Westminster John Knox Press, Louisville, KY.

Ricoeur, P., 1990, Oneself as another, University of Chicago Press, Chicago, II.

Ruthrof, H., 2000, The body in language, Cassell, London.

Sheets-Johnstone, M., 1990, The roots of thinking, Temple University Press, Philadelphia.

Sheets-Johnstone, M., 1994, The roots of power: animate form and gendered bodies, Open Court Publishing Company, Illinois.

Sheets-Johnstone, M., 2008, The roots of morality, Penn State University Press, Pennsylvania.

Sheets-Johnstone, M., 2009, The corporeal turn. An interdisciplinary reader, Imprint Academic, Exeter.

Solomon, J., 2007, Living with X. A body mapping journey in the time of HIV and AIDS. facilitator's guide, REPSSI, Johannesburg.

Surkis, J., 2012, 'When was the linguistic turn? A genealogy', The American Historical Review 117(3), 701-711. http://dx.doi.org/10.1086/ahr.117.3.700

Todres, L., 2011, Embodied enquiry: Phenomenological touchstones for research, psychotherapy and spirituality, Palgrave Macmillan, Hampshire.

Turner, B., 1996, The body and society. Explorations in social theory, 2nd edn., Sage, London.

Vico, G., 1968, The new science of Giambattista Vico, Cornell University Press, New York.

White, M., 2011, Narrative practice: Continuing the conversations, W.W Norton \& Company, London. 